\title{
ON THE ASSOCIATION OF IRANIAN EFL TEACHER'S IDENTITY STYLE, RELIGIOUS IDENTITY, AND IDENTITY COMMITMENT
}

\author{
MOHAMMAD ALIAKBARI, FIAN GHASEMI* \\ English Department, Ilam University, Iran \\ *Email: fian.ghasemi@yahoo.com
}

Received: 24 May 2021, Revised and Accepted: 3 August 2021

\begin{abstract}
The purpose of the present study was to investigate the relationship among EFL teacher's identity style, religious identity, and identity commitment. The data was collected from $88 \mathrm{EFL}$ teachers teaching at different English language learning institutes in Ilam provinceIran. Two questionnaires were used, including Dollinger's (2001) Brief Religiosity Scale (BRS-6) and Berzonsky's (1992) Identity Style Inventory, the revised version (ISI3). Results suggested that EFL teacher's identity style and their commitment were positively correlated $(\mathrm{r}=0.350)$. There was also a significant positive correlation between EFL teacher's religious identity and their commitment $(\mathrm{r}=0.312)$. A significant positive correlation was also found between EFL teacher's identity style and religious identity $(r=0.367)$. The results of oneway ANOVA indicated that there was a statistically significant difference in identity style scores, identity commitment scores, and religiosity scores for four groups. The results of independent $t$-test analysis indicated that there was no significant difference in identity style, identity commitment, and the religiosity scores of the two groups of participants. Finally, the implications and limitations of the study were also discussed.
\end{abstract}

Keywords: EFL teacher, Identity style, Religious identity, Identity commitment.

(C) 2021 The Authors. Published by Innovare Academic Sciences Pvt Ltd. This is an open access article under the CC BY license (https://creativecommons.org/licenses/by/4.0/) DOI: https://dx.doi.org/10.22159/ijoe.2021v9i6.42163. Journal homepage: https://innovareacademics.in/journals/index.php/ijoe

\section{INTRODUCTION}

Identity development during adolescence has been the subject of interest for many individuals, especially for psychologists. People experience many challenges during this period of their life. Marcia (1966) and Berzonsky (1989) have proposed models for identity style development in order to help individuals to gain a better understanding of the process of identity formation in adolescents. Marcia's (1966) model of identity development includes four statuses as Achievement, Foreclosure, Moratorium, and Diffusion. Employing a social-cognitive perspective to Marcia's statuses, Berzonsky (1989) suggests that individuals in Marcia's achievement and moratorium statuses are inclined to utilize an Informational processing style; foreclosed individuals utilize a Normative processing style and diffused individuals utilize a Diffused/Avoidant processing style. According to Dollinger (2001), many psychologists and sociologists have pointed out that because of the identity-conferring nature of religiosity, many people claim that they have a religious identity. Several factors, including gender, ethnicity, culture, and religion play an important role in developing an individual's identity. Among these factors, religion has been considered as an ideological propagation rather than as a set of beliefs. According to Cheng and Beig (2012), educational institutes such as schools or universities play an important role in helping students to better understand the concept of religion. Furthermore, researchers (Johnston, 2003; Varghese \& Johnston, 2007; Wicking, 2012) have emphasized the significant role of teacher's moral and religious beliefs and their impact on their teaching and interactions with students. However, studies have been conducted on identity styles in western countries such as Belgium, Netherland, Australia, Canada, Greece, Italy, Korea and Slovakia; little if any has been conducted in non-western countries like Iran and, especially, among EFL teachers. Therefore, the purpose of the present study is to investigate the relationship of these three variables, namely, identity style, religious identity, and identity commitment among Iranian EFL teachers.

\section{REVIEW OF THE RELATED LITERATURE}

\section{Identity style}

In order to provide a clear picture of the concept of identity, researchers (Berzonsky, 1989; Marcia, 1966) have offered various models and definitions. The identity status theory has been presented by Marcia (1966), which is concerned with the degree of an individual's identity exploration and commitment Marcia (1966) developed an identity status model in order to assess the ego identity of eighty-six college male students. Two criteria, including crisis and commitment, have been used in order to construct an identity status model. In this model, the crisis has been referred to as "adolescent's period of engagement in choosing among meaningful alternative" ( $p$. 551). Commitment has been referred to as "the degree of personal investment the individual exhibits" (p. 551). Four statuses have been distinguished. An identity achievement, which refers to as a committed individual who experienced a crisis period; the identity-diffusion, which refers to as an uncommitted individual who may or may not experience a crisis period; moratorium, which referred to as an uncommitted individual who was in the crisis period; and finally, foreclosure, which refers to a committed individual who has not experienced a crisis. Berzonsky (1989) has focused on various social-cognitive strategies that people utilize in different situations in order to construct and maintain their sense of identity. He developed an identity processing style model including two dimensions: Exploration and Commitment. An exploration dimension included informational, normative, and diffuse-avoidant scales; the commitment dimension included the identity commitment scale. The first dimension of this model namely, informational identity style, included exploring and searching relevant information before making decisions. The second dimension, normative identity style, included adopting others, not their values and goals, as appropriate sources. The third dimension of this model, diffuse-avoidant identity style, included relying on situational consequences and rewards in order to direct an individual's decisions and behaviors. Based on Marcia's (1966) identity-status model, individuals who are identity achieved or in moratorium tend to use an information identity style. They tend to search, elaborate, and utilize relevant information actively in order to make the right choice. Based on this model, individuals who are foreclosed are supposed to apply a normative identity style. Conforming to the normative standards of important individuals such as parents are their major concerns. Finally, individuals who are in identity diffusion status avoid dealing directly with personal problems and basic identity questions. This diffuse, avoidant 
orientation involves not taking a course of action until situational results are recognized.

\section{Identity commitment}

Berzonsky (2003) referred to identity commitment as "the strength or clarity of the self-relevant standards, goals, convictions, beliefs, and the like that one holds" (p. 132). By providing people with a sense of purpose and direction, Brickman, Sorrentino and Wortman (1987) emphasized that commitment "stabilizes individual behavior under circumstances where the individual would be otherwise tempted to change" (p. 133). Identity commitment is shown to be associated with identity processing styles. Berzonsky (2003) conducted a study in order to investigate the role of identity processing styles and identity commitment in personal well-being. The researcher argued for the importance of identity commitment research in illuminating the relationship between identity processing styles and the outcome variable. He proposed three models, including a direct-effects model, a mediated-effects model, and a moderated-effects model that are applied in commitment and processing styles, which impact the outcome variables. Regarding the relationship between identity commitment and identity style, Bosch and Card (2012) and Berzonsky (1992) have indicated that there is a positive association between commitment and both informational and normative identity style and a negative association between commitment and diffuse-avoidant style.

\section{Religious identity}

Researchers (Allport \& Ross, 1967; Argyle \& Beit-Hallahmi, 1975; Batson, Floyd, Meyer, \& Winner, 1999; Clark, 1958; Dollinger, 2001; Doyle, 1992; McCrae, 1999; Rahner \& Vorgrimler, 1981; Roccas, Sagiv, Schwartz, \& Knafo, 2002; Zinnbauer, Pargament, \& Scott, 1999) have offered different definitions for religiosity. Some considered religiosity as an ideology or a set of acquired beliefs and practices (McCrae, 1999). Doyle (1992) defined religiosity as "practices carried out by those who profess a faith" (p. 303). These practices included praying, reading Bible, receiving sacraments, devoting time to doing these practices. The author assumed that religions, cultures, and religious practices are related to each other. Rahner and Vorgrimler (1981) defined religiosity as "concern with the ground and purpose of the world we call God" (p. 437). The term religious identity has been used and conceptualized in many different ways ranging from focusing on the inner (i.e., personality) vs. the outer (i.e., social or collective group) (Dollinger, 2001). Dollinger (2001) referred to religious identity as "offering any of the potentially infinite arrays of "religious" answers to the classic question" (p. 72). Roccas et al. (2002) compared religion with evaluation and justification of choices and actions because both evaluation and justification were based on goals. Allport and Ross (1967) argued that religion was not only a value; it also served an individual's needs in that a person with a specific religious orientation utilized his/her religious views in order to provide security, comfort, status, or social support for himself/herself The researchers also argued that crucial distinctions should be made between religious attitudes such as intrinsic, extrinsic, and indiscriminately pro-religious and, at the same time, highly prejudiced. Moreover, Knowing the role of religion in everyone's life was more important than knowing whether a person was religious or not. Argyle and Beit-Hallahmi (1975) viewed religion as "a system of beliefs in a divine or superhuman power, and practices of worship or other rituals directed towards such a power" (p. 1). Batson et al. (1993) defined religion as "whatever we as individuals do to come to grips personally with the questions that confront us because we are aware that we and others like us are alive and that we will die" (p. 8). Clark (1958) proposed another definition for religion as "the inner experience of the individual when he senses a Beyond, especially as evidenced by the effect of this experience on his behavior when he actively attempts to harmonize his life with the Beyond" (p. 22). Zinnbauer et al. (1999) referred to three major aspects of traditional psychological research on religion. The first one regarded religion as "broad-band" construct and it was not different from spirituality. The second aspect of traditional psychological research focused on personal aspects of religiousness. And finally, the third aspect focused on the positive and negative forms of faith. By integrating the two constructs, namely, religion and spirituality, Zinnbauer et al. (1999) suggested an alternative approach to the emerging meanings of religion and spirituality in order to acknowledge the ways in which people expressed their religiousness and spirituality.

\section{Religiosity and identity}

Duriez, Soenens and Beyers, (2004) proposed an important question regarding the relationship between the two concepts of identity and religiosity. They asked whether or not identity development was related to the acquisition of religious beliefs. They further pointed out that the lack of a common theoretical framework regarding their relationship made it difficult to interpret the results of such research. However, Parker (1985) found a positive relationship between identity development and religiosity; whereas, Markstrom-Adams (1999) found no relationship between these concepts.

Related studies on identity styles, commitment, and religiosity

Several studies have been conducted on identity styles, commitment, and religiosity or the possible relationship between these variables. Some have investigated personality, identity styles, and religiosity (Duriez, Soenens, \& Beyers, 2004). Identity development and religiosity during adolescence (Markstrom, 1999; Markstrom, Hofstra, \& Dougher, 1994 Tzuriel, 1984; Verhoeven \& Hutsebaut, 1995) empirical research on identity (Berzonsky \& Adams, 1999; Marcia, 1980 Waterman, 1982); and identity styles, commitment and religiosity (Grajales \& Sommers, 2016). Tzuriel (1984) investigated the relation between (a) sex-role typing and ego identity, (b) the distribution of sex-role typing within different cultural groups, and (c) the relative contribution of masculinity, femininity, religiousness, sex, and ethnic origin to the prediction of ego identity variables among Oriental and Western Israeli students from religious and secular high schools (AT $=1,207)$. The data were collected using completing the Bar-Han Sex Role Inventory (BI-SRI) and the Adolescent Ego Identity Scale (AEIS). The results of the study showed that more androgynous, less sex-typed, and less undifferentiated adolescents were among Orientals than among Westerners. Sex role type was significantly related to each of the ego identity variables. Boys scored higher than girls on Solidity and Continuity but lower on Social Recognition. Westerners scored higher than Orientals on Commitment and Purposefulness and Total Ego Identity. Religious adolescents scored higher than secular adolescents on Commitment and Purposefulness. An interaction of ethnic origin and school type on Solidity and Continuity indicated that Oriental religious subgroups scored higher than any other subgroups. Berzonsky and Adams (1999) observed change rather than stability in status among university students. Moreover, the results indicated that status changes were more likely to be progressive rather than regressive in terms of the hypothesized identity status developmental sequence. However, considerable status regression and fluctuation were observed. The researchers concluded that focusing on the social-cognitive processes and conceptualizing these identity orientations was a useful strategy for university students. Duriez et al. (2004) investigated the relationship between the two main dimensions of the religiosity domain and the Five-Factor Model of personality and Berzonsky's (1990) identity style in a Flemish sample of late adolescents. The results of the study showed that, whereas Exclusion vs. Inclusion was unrelated to any of the personality dimensions, Literal vs. Symbolic was strongly related to Openness to Experience and moderately to Agreeableness. Further, it was shown that Exclusion vs. Inclusion was positively related to the normative identity style and that Literal vs. Symbolic correlated positively with the informational identity style and negatively with the diffuse/avoidant identity style. As expected, the relation 
between Openness to Experience and Literal vs. Symbolic was fully mediated by the informational identity style. Once Openness to Experience was taken into account, Agreeableness was no longer an important determinant of Literal vs. Symbolic. This study

The review of literature has indicated a small positive association between gender and diffuse-avoidant identity style Thus, the three factors of age, country of origin, and sex differences are considered possible moderators of the formation of identity (Bosch \& Card, 2012). However, many studies have been conducted on identity styles in western countries such as Belgium, The Netherland, Australia, Canada, Greece, Italy, Korea and Slovakia; little if any has been conducted in non-western countries like Iran and especially among EFL teachers.

\section{RESEARCH QUESTIONS}

The purpose of the present study was to investigate the relationship among these three variables: Identity style, Religious identity, and Identity commitment among Iranian EFL teachers. The present study was guided by the following research questions:

1. Is there any significant relationship between identity style and identity commitment?

2. Is there any significant relationship between religious identity and identity commitment?

3. Is there any significant relationship between identity style and religious identity?

4. Is there any significant difference among participants of different ages and gender regarding their identity style?

5. Is there any significant difference among participants of different ages and gender regarding their identity commitment?

6. Is there any significant difference among participants of different ages and gender regarding their religiosity?

\section{METHODOLOGY}

\section{Participants}

Eighty-eight EFL teachers (30 males and 58 females) participated in this study. The sample was drawn from teachers who were teaching English at different English learning institutes in Iran- Ilam province. The level of teacher's education was B. A (Bachelor of Arts) and M.A (Master of Arts) The teacher's age ranged from 22 to $42(M=31.5)$. They were native speakers of Persian.

\section{Instrumentation}

In the present study, two questionnaires were used to collect data: Dollinger's (2001), The Brief Religiosity scale (BRS-6) and Berzonsky's (1992) The Identity Style Inventory, revised version (ISI3).

\section{The Brief Religiosity Scale (BRS-6)}

The BR-6 is an eight-item self-report measure, of which five questions address behavioral, cognitive, and affective aspects of religiosity, and one question addresses spirituality. Two questions that address religious viewpoints were excluded from analysis (Question 1 and 2, because of redundancy). Responses were rated on a Likert-type scale with anchors 1 (Never/Not at all) to 5 (Very frequently/Extremely so). The coefficient alpha for the scale has been reported to be 0.85 (Dollinger, 2001).

\section{The Identity Style Inventory, revised version (ISI3)}

The ISI3 is a 40-item self-report instrument that measures Berzonsky's informational, normative, and diffuse-avoidant identity styles as well as identity commitment. Responses were rated on a Likert-type scale with anchors 1 (Strongly Disagree) to 5 (Strongly Agree).

\section{Data collection procedure}

The two questionnaires were administered to the English teachers in the English language learning institutes by the researcher. The researcher asked teachers to complete the questionnaires and bring them back the next day. Thus they were given enough time and instruction to provide the answer to these questionnaires.

\section{Data analysis}

After collecting the data, the researcher utilized Statistical Package for the Social Sciences (SPSS) 21 for quantitative analysis of the data. The correlation test was used to determine whether there was a relationship between identity style and identity commitment, between religious identity and identity commitment, and between identity style and religious identity. Because the data were ordinal, the researcher used the Spearman correlation to determine whether there were significant differences among EFL teachers with respect to their gender, an independent t-test was run. Finally, to investigate whether there were significant differences among EFL teachers with respect to their age, a one-way ANOVA was conducted.

\section{RESULTS}

In order to answer Research Question (RQ)1, RQ2, and RQ3 regarding the relationship between identity style and identity commitment, between religious identity and identity commitment, and between identity style and religious identity, Spearman-rho Correlation Coefficient was run. To answer RQ1, analysis of the data indicated that EFL teacher's identity style and their commitment were positively correlated ( $\mathrm{r}=.350)$. This positive correlation is indicated in table 1 and suggests that there is a relationship between identity style and commitment of the EFL teachers.

Table 1: Teacher's IS and IC

\begin{tabular}{|c|c|c|}
\hline & & ICtot \\
\hline \multirow{3}{*}{ IStot } & Spearman's rho correlation & $0.350 * *$ \\
\hline & Sig (two-tailed) & 0.000 \\
\hline & $\mathrm{N}$ & 88 \\
\hline
\end{tabular}

RQ2 examined the relation between EFL teacher's religious identity and their commitment. As shown in table 2, the correlation between EFL teacher's religious identity and their commitment is significant $(\mathrm{r}=0.312)$.

Table2: Teacher's RI and IC

\begin{tabular}{|l|l|c|}
\hline \multicolumn{2}{|c|}{ ICtot } \\
\hline \multirow{3}{*}{ RItot } & Spearman's rho correlation & $0.312^{* *}$ \\
\cline { 2 - 3 } & Sig (two-tailed) & 0.000 \\
\cline { 2 - 3 } & $\mathrm{N}$ & 88 \\
\hline \multicolumn{2}{|c|}{ Note: RItot: religious identity total; ICtot: Identity commitment.*. Correlation is }
\end{tabular}
significant at the 0.01 level.

RQ3 examined the relation between EFL teacher's identity style and religious identity. As shown in table 3, the correlation between EFL teacher's identity style and religious identity is significant $(\mathrm{r}=0.367)$.

Table 3: Teacher's IS and RI

\begin{tabular}{|l|l|c|}
\hline \multicolumn{2}{|c|}{} & RItot \\
\hline \multirow{3}{*}{ IStot } & Spearman's rho correlation & $0.367^{* *}$ \\
\cline { 2 - 3 } & Sig (two-tailed) & 0.000 \\
\cline { 2 - 3 } & $\mathrm{N}$ & 88 \\
\hline \multirow{2}{*}{ Note: IStot: identity style total; RItot: religious identity. ${ }^{* *}$.Correlation is significant }
\end{tabular}
at the 0.01 level.

In order to answer RQ 4, RQ5, and RQ6 regarding EFL teacher's identity style, identity commitment, and religiosity, with respect to their age, an analysis of variance (one-way ANOVA) was run. The results of this statistical analysis are presented in table 4. Participants were divided into four groups according to their age $(22-27 ; 28-32 ; 33-37 ; 38-42)$. There was a statistically significant difference at the $\mathrm{p}<$ 0.000 level in identity style scores $(F=0.788, p<0.001)$ for the four age groups, identity commitment scores for four age groups $(\mathrm{F}=0.677, \mathrm{P}<0.000)$, and religiosity scores for four groups $(\mathrm{F}=0.681, \mathrm{P}<0.000)$. 
Innovare Journal of Education, Vol 9, Issue 6, 2021, 1-6

Table 4: One-way ANOVA results for teacher's identity style, identity commitment, and religiosity regarding their age

\begin{tabular}{|c|c|c|c|c|c|c|}
\hline Variables & Groups & Sum of squares & df & Mean square & F-value & Sig. \\
\hline \multirow{3}{*}{ Identity style } & Between groups & 1302.763 & 22 & 59.216 & 0.788 & 0.728 \\
\hline & Within groups & 4881.555 & 65 & 75.101 & & \\
\hline & Total & 6184.318 & 87 & & & \\
\hline \multirow{3}{*}{ Commitment } & Between groups & 92.802 & 22 & 4.218 & 0.677 & 0.846 \\
\hline & Within groups & 405.198 & 65 & 6.234 & & \\
\hline & Total & 498.000 & 87 & & & \\
\hline \multirow{3}{*}{ Religiosity } & Between groups & 170.224 & 22 & 7.737 & 0.681 & 0.841 \\
\hline & Within groups & 738.276 & 65 & 11.358 & & \\
\hline & Total & 908.500 & 87 & & & \\
\hline
\end{tabular}

In order to answer RQ 4, RQ 5, and R6 regarding EFL teacher's identity style, identity commitment, and religiosity with reference to their gender, independent t-test analysis was conducted. As can be seen table 5 , there was no significant difference in scores of the two groups of participants [t $(86)=0$. $605, \mathrm{p}=0.547]$, with identity style female group scoring higher $(M=101, S D=8.17)$ than male group $(M=100.18, S D=8.83)$.
There was also no significant difference in scores of the two groups of participants[t $(86)=-0.448, p=0.656]$ identity commitment female group scoring higher $(M=20.40, S D=2.49)$ than male $\operatorname{group}(M=20.63, S D=2.27)$; and there was no significant difference in scores of the two groups of participants $[\mathrm{t}(86)=0.564, \mathrm{p}=0.574]$ religiosity female group scoring higher $(M=31.42, S D=3.23)$ than male $\operatorname{group}(M=31.03, S D=3.2)$.

Table 5: Independent sample t-test result for teacher's identity style, identity commitment, and religiosity with respect to gender

\begin{tabular}{|l|l|c|c|c|c|c|c|c|}
\hline \multicolumn{1}{|c|}{ Variables } & Group & N & Mean & SD & df & t-value & Sig. & Sig. (2-tailed) \\
\hline \multirow{2}{*}{ Identity style } & Female & 50 & 101.18 & 8.17 & \multirow{2}{*}{86} & \multirow{2}{*}{0.605} & \multirow{2}{*}{0.604} & 0.547 \\
& Male & 38 & 100.07 & 8.83 & \multirow{2}{*}{0.46} & \multirow{2}{*}{0.656} \\
\hline \multirow{2}{*}{ Identity commitment } & Female & 50 & 20.40 & 2.49 & \multirow{2}{*}{86} & -0.448 & \multirow{2}{*}{0.668} & \multirow{2}{*}{0.574} \\
\hline \multirow{2}{*}{ Religiosity } & Male & 38 & 20.63 & 2.27 & & \multirow{2}{*}{0.081} & \\
\hline
\end{tabular}

\section{DISCUSSION}

The purpose of the present study was to investigate the relationship among identity style, identity commitment, and religiosity of EFL Iranian teachers. In order to explore their relationship, six questions were asked. The results of the first question regarding the relationship between identity style and identity commitment showed that there was a significant positive correlation between identity styles and identity commitment. Berzonsky (1989), in his model, proposed that the predictive power of identity style on any outcome variable is mediated by identity commitment. Based on this statement, Grajales and Sommers (2016) considered religiosity as an outcome variable. They found that Berzonsky's identity styles model fit their sample in that they predicted that identity styles would be predictive of Dollinger's religiosity, as it is mediated by identity commitment. In this regard, the Informational style and normative style had positive effects, whereas the diffuse/avoidance style had a negative effect on commitment. Regarding the relationship between religious identity and identity commitment, there was a significant positive correlation between these variables. This result is in line with those of Grajales \& Sommers (2016) in that Grajales and Sommers (2016) found that commitment was positively related to religiosity. The third question examined the relationship between identity style and religiosity. In the present study, the researcher found a significant positive correlation between these variables. This result is in line with Grajales and Sommers's (2016) finding. They found that informational identity style was positively related to religiosity. With regard to RQ4 that examined the role of age and gender in identity style, significant differences were found among EFL teachers with different age groups. In previous research studies, age has been tested as a moderator in measuring the status of identity styles (i.e., whether identity styles remain constant or not) (Bass \& cord, 2012). Bass and Card (2012) considered three developmental groups, including high school students, college students, and adults, because these groups are believed to experience different events during their life with regard to their identity development. In the current study, there was not a significant difference between the identity style of male and female EFL teachers, with female teachers reporting higher identity style. Regarding the role of age and gender in identity commitment (RQ5), it was found that there was no significant difference between identity commitments of EFL teachers with different age groups. It was also found that there is no significant difference in identity commitment of the male and female groups, with female teachers reporting higher identity commitment. Regarding the role of age and gender in religiosity (RQ6), it was found that there was a significant difference among the participants of different ages. In other words, age has had an important role in the EFL teacher's religiosity. Duriez et al. (2004) found that individuals who use an informational identity style interpret religious contents in a more personal and symbolic way. This indicates that information-oriented individuals critically evaluate whether there is a connection between religious contents and their personal self-definition (Berzonsky, 1990 as it is cited in Duriez et al., 2004). The findings of the present study also indicated that there were significant gender differences among participants concerning their religiosity.

\section{CONCLUSION}

It is important to take into account the relationship between identity style, commitment, and religiosity in order to gain a better understanding of the nature of their interactions. Due to the important role of teachers in the educational system, especially in EFL classrooms, the relationships between these variables were investigated in this study. Regarding the religious identity of teachers, especially where religion is an important aspect of society, it is necessary to ask teachers to express their religious ideas and negotiate them in an ELT context. The results indicated that age and gender played an important role in mediating the relationship between these variables. Participants of different ages and gender held a different point of view with respect to these variables. Teachers need to understand the interaction of their identity styles, commitment, and religiosity because it may affect students' learning.

\section{Implications}

The result of the study has important implications for teacher development. It shed light on teacher's identity style, commitment and religiosity in the ELT classroom. It is also 
provided useful information about different points of view which teachers of different ages and gender held. The findings of the study may also be useful for English-language teachers in that they should not ignore their religious identity. Religious identity is an important aspect of many people's, including teacher's lives and it cannot be excluded from their lives. Limitations

It is important to point out that the present study included a small sample of EFL teachers. Thus, it may not be representative of the whole population of EFL teachers in the context of Iran. Larger sample size would help in providing a better and clearer picture of Iranian EFL teacher's identity style, commitment and religiosity.

\section{ACKNOWLEDGMENT}

We would like to thank reviewers for their insights. We would also like to show our gratitude to the principals and teachers who aid us during the course of research.

\section{CONFLICT OF INTEREST}

The authors declare that there is no conflict of interest.

\section{AUTHORS CONTRIBUTORS}

Prof. Mohammad Aliakbari and Fian Ghasemi designed the research, Prof. Aliakbari was involved in planning and supervising the work. Fian Ghasemi performed the analysis, drafted the manuscript and interpreted the results and worked on the manuscript. Both authors discussed the results and commented on the manuscript.

\section{FUNDING SOURCE}

No funding.

\section{REFERENCE}

- $\quad$ Allport, G. W., \& Ross, J. M. (1967). Personal religious orientation and prejudice. Journal of Personality and Social Psychology, 5(4), 432-443. doi:10.1037/h0021212

- $\quad$ Batson, C. D., Floyd, R. B., Meyer, J. M., \& Winner, A. L. (1999). "And who is my neighbor?: "Intrinsic religion as a source of universal compassion. Journal for the Scientific Study of Religion, 38(4) 445-457. doi:10.2307/1387605

- $\quad$ Beit-Hallahmi, B., \& Argyle, M. (1975). God as a fatherprojection: The theory and the evidence. British Journal of Medical Psychology. doi:10.1111/j.2044 8341.1975.tb02310.x

- $\quad$ Berzonsky, M. D. (1989). Identity style: Conceptualization and measurement. Journal of Adolescent Research, 4(3), 268-282. doi:10.1177/074355488943002

- Berzonsky, M. D. (1992). Identity style and coping strategies. Journal of Personality, 60(4), 771-788. doi:10.1111/j.1467-6494.1992.tb00273.x

- Berzonsky, M. D. (2003). Identity style and well-being: Does commitment matter? Identity, 3(2), 131-142. doi:10.1207/S1532706XID030203

- Berzonsky, M. D. (2008). Identity formation: The role of identity processing style and cognitive processes. Personality and Individual Differences, 44(3), 645-655. doi:10.1016/j.paid.2007.09.024

- $\quad$ Berzonsky, M. D., \& Adams, G. R. (1999). Reevaluating the identity status paradigm: Still useful after 35 years. Developmental Review, 19(4), 557-590. doi.:10.1006/drev.1999.0495

- $\quad$ Berzonsky, M. D., Soenens, B., Luyckx, K., Smits, I., Papini, D. R., \& Goossens, L. (2013). Development and validation of the revised Identity Style Inventory (ISI-5): Factor structure, reliability, and validity. Psychological Assessment, 25(3), 893-904. doi:10.1037/a0032642

- $\quad$ Bosch, L. A., \& Card, N. A. (2012). A meta-analytic review of Berzonsky's Identity Style Inventory (ISI). Journal of
Adolescence, 35(2)

$333-343$. doi:10.1016/j.adolescence.2011.08.007

- Brickman, P., Sorrentino, R. M., \& Wortman, C. B. (1987). Commitment, conflict, and caring. Englewood Cliffs, NJ: Prentice-Hall.

- $\quad$ Cheng, K. K. Y., \& Beigi, A. B. (2012). Education and religion in Iran: The inclusiveness of EFL (English as a Foreign Language) textbooks. International Journal of Educational Development, 32(2), 310-315. doi:10.1016/j.ijedudev.2011.05.006

- Clark, W. H. (1958). How do social scientists define religion?. The Journal of Social Psychology, 47(1), 143-147. doi:10.1080/00224545.1958.9714350

- Dollinger, S. J. (2001). Religious identity: An autophotographic study. The International Journal for the Psychology of Religion, 11(2), 71-92. doi:10.1207/S15327582IJPR1102_01

- Dollinger, S. J., \& Malmquist, D. (2009). Reliability and validity of single-item self-reports: With special relevance to college students' alcohol use, religiosity, study, and social life. The Journal of General Psychology, 136(3), 231242. doi:10.3200/GENP.136.3.231-242

- Dollinger, S. J., Clancy Dollinger, S. M., \& Centeno, L. (2005). Identity and creativity. Identity, 5(4), 315-339. doi:10.1207/s1532706xid05042

- $\quad$ Doyle, D. (1992). Have we looked beyond the physical and psychosocial?.Journal of Pain and Symptom Management, 7(5), 302-311. doi:10.1016/08853924(92)90063-N

- Duriez, B., Soenens, B., \& Beyers, W. (2004). Personality, identity styles, and religiosity: An integrative study among late adolescents in Flanders (Belgium). Journal of Personality, 72(5), 877-910. doi:10.1111/j.0022 3506.2004.00284.x

- $\quad$ Grajales, T. E., \& Sommers, B. (2016). Identity styles and religiosity: Examining the role of identity commitment. Journal of Research on Christian Education, 25(2), doi:10.1080/10656219.2016.1191394

- Johnston, B. (2003). Values in English language teaching. Routledge.

- Kroger, J. (1997). Gender and identity: The intersection of structure, content, and context. Sex Roles, 36(11-12), 747770. doi:10.1023/A:1025627206676

- Marcia, J. E. (1966). Development and validation of egoidentity status.Journal of Personality and Social Psychology, 3(5), 551-558. doi:10.1037/h0023281

- $\quad$ Marcia, J. E. (1967). Ego identity status: Relationship to change in self-esteem, "general maladjustment," and authoritarianism1. Journal of Personality, 35(1), 118-133. doi:10.1111/j.1467-6494.1967.tb01419.x

- Marcia, J. E. (1980). Identity in adolescence. In Handbook of adolescent psychology (pp.109-137). New York: Wiley.

- Markstrom, C. A. (1999). Religious involvement and adolescent psychosocial development. Journal of Adolescence, 22(2), 205-221. doi:10.1006/jado.1999.0211

- $\quad$ Markstrom-Adams, C., Hofstra, G., \& Dougher, K. (1994). The ego-virtue of fidelity: A case for the study of religion and identity formation in adolescence. Journal of Youth and Adolescence, 23(4), 453-469. doi:10.1007/BF01538039

- $\quad$ McCrae, R. R. (1999). Mainstream personality psychology and the study of religion. Journal of Personality, 67(6), 1209-1218. doi:10.1111/1467-6494.00088

- Parker, M. S. (1985). Identity and the development of religious thinking. New Directions for Child and Adolescent Development, 1985(30), doi:10.1002/cd.23219853005

- $\quad$ Rahner, K. (1981). Dictionary of theology (2nd ed.). New York: Crossroads.

- $\quad$ Roccas, S., Sagiv, L., Schwartz, S. H., \& Knafo, A. (2002). The big five personality factors and personal values. Personality and Social Psychology Bulletin, 28(6), 789-801. doi:10.1177/0146167202289008 
- $\quad$ Tzuriel, D. (1984). Sex role typing and ego identity in Israeli, Oriental, and Western adolescents. Journal of Personality and Social Psychology, 46(2), 440-457. doi:10.1037/0022-3514.46.2.440

- Varghese, M. M., \& Johnston, B. (2007). Evangelical Christians and English language teaching. TESOL Quarterly, 41(1), 5-31. doi:10.1002/j.15457249.2007.tb00038.x

- Verhoeven, D., \& Hutsebaut, D. (1995). Identity status and religiosity. Journal of Empirical Theology,8(1), 46-64. doi:10.1163/157092595X00115
- Waterman, A. S. (1982). Identity development from adolescence to adulthood: An extension of theory and a review of research. Developmental psychology, 18(3), 341. doi:10.1037/0012-1649.18.3.341

- Wicking, P. (2012). God in the classroom. The Language Teacher, 36(5), 35-38. Retrieved from https://jaltpublications.org/files/pdf-article/36.5tlt-art3.pdf

- Zinnbauer, B. J., Pargament, K. I., \& Scott, A. B. (1999). The emerging meanings of religiousness and spirituality: Problems and prospects. Journal of Personality, 67(6), 889-919. doi:10.1111/1467-6494.00077 